International Journal of Instruction

e-ISSN: 1308-1470 • www.e-iji.net
July $2019 \bullet$ Vol.12, No.3

p-ISSN: 1694-609X

pp. 699-716

Received: 25/10/2018

Revision: 23/04/2019

Accepted: 28/04/2019

OnlineFirst:22/05/2019

Effects of Instructional Models and Spatial Intelligence on the Mathematics Learning Outcomes after Controlling for Students' Initial Competency

\author{
Mohamad Salam \\ Dr., Department of Mathematics Education, Halu Oleo University, Kendari, Indonesia, \\ mohamad.salam@uho.ac.id
}

\title{
Nurdin Ibrahim
}

Prof., Jakarta State University, Indonesia,nurdin1349@yahoo.com

Moch Sukardjo

Dr., Jakarta State University, Indonesia, asukardjo@yahoo.com

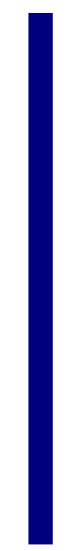

The present study determined the effects of instructional models and spatial intelligence on students' mathematics learning outcomes after controlling for their initial competence. The study was conducted at Senior High School (SHS) 6 Kendari, Indonesia using a quasi-experimental method designed by level $2 \times 2$. Samples consisted of 40 students selected randomly. The data were analyzed using either two-way ANCOVA at the 0.05 significance level. The results showed that mathematics learning outcome of students who were taught by integrative instruction was higher than those taught by direct instruction after controlling the initial competency. There is an interaction effect between the instructional model and spatial intelligence on mathematics learning outcome. Learning outcome of students who have high spatial intelligence and taught by integrative instruction was higher than those taught by direct instruction, and learning outcome of students who have low spatial intelligence and taught by integrative instruction was lower than those taught by direct instruction.

Keywords: integrative model, direct model, spatial intelligence, learning outcome, initial competency

\section{INTRODUCTION}

Learning should be an "empowering process", a fun and continuous process established in a sustainable manner to develop the potency of learners (students) and enhancing their knowledge for solving their current and future problems. Students who will compete for success in their future life must be able to learn new concepts and skills. In

Citation: Salam, M., Ibrahim, N., \& Sukardjo, M. (2019). Effects of Instructional Models and Spatial Intelligence on the Mathematics Learning Outcomes after Controlling for Students' Initial Competency. International Journal of Instruction, 12(3), 699-716. https://doi.org/10.29333/iji.2019.12342a 
mathematics learning, to date, many students still regard mathematics as "complicated" and "difficult" subject. They express this status quo in psychological or physical phenomena such as "despair", "stress", "demotivation", "depression", "fear", "fatigue", "headache" and "nausea". These expressions illustrate that mathematics learning applied by teachers has not been a fun activity and is often irrelevant to daily real-life experiences. In a substantial sense, the learning process up to now has not provided access for students to develop independence through discovery in the process of thinking. Students activity is more emphasized by listening and recording the material given by the teacher, hence they are become passive, unfocused and feel bored. As a result, students' learning outcomes in mathematics are still low and have not reached yet the minimum criteria targeted by the school.

The low mathematics learning outcomes were also experienced by 11th-grade students in Senior High School (SHS) 6 Kendari. The average mathematics learning outcomes for this school can be seen in table 1 below.

Table 1

Mathematics Learning Outcomes of 11th-Grade Students Majoring in Science in the Last Three Years

\begin{tabular}{lllll}
\hline \multirow{2}{*}{ School year } & $\begin{array}{l}\text { Number of } \\
\text { students }\end{array}$ & \multirow{2}{*}{ Average } & \multicolumn{2}{c}{ Percentage (\%) } \\
\cline { 4 - 5 } & 134 & 60.93 & 87.3 & 12.7 \\
2015 & 136 & 62.5 & 89 & 11 \\
2016 & 118 & 64.19 & 80 & 20 \\
\hline
\end{tabular}

Table 1 above gives the meaning that the average mathematics learning outcomes in 2015 were 60.93 with the percentage of students below the minimum completeness criteria (MMC) as much as $87.3 \%$. In 2016, the average score of mathematics subjects was 62.5 with $89 \%$ of students below the MCC, and in 2017 as many as $20 \%$ of students already met the MCC, yet $80 \%$ were still under the MCC. This data provides a very clear depiction that the values obtained by students have not met the minimum competency standards that must be mastered (Source: Deputy head of the curriculum field of SHS 6 Kendari, 2018). One of the causes of the low learning outcomes is that students are only trained to do practice questions in the textbook without being implanted in a deep concept of building knowledge, but not trained to think critically.

Previous studies, e.g., Ishaq \& Awang (2017), Wahid, Yusof, \& Razak (2013), and Pehlivan \& Durgut (2017) summarized that there are many factors influence learning outcomes, both by internal and external factors from the student. The internal factors include learning motivation, level of intelligence, and learning styles, while external factors comprise instructional models used by teachers, learning strategies, learning approaches, learning methods and the ability of teachers in managing to learn in the classroom. In mathematics learning, in addition to the above factors, Acharya (2017) found several other factors that led to the difficulty of learning mathematics which has an impact on the learning outcomes, such as negative perceptions and anxiety to mathematics subject, as well as the low of initial competence of the new material being studied. Initial competence is the sum of a person's previous learning and experiences 
(Cooper, et.al., 2018). Moreover, Murphy \& Alexander (2005) emphasized that Initial competence is the sum of what an individual knows.

According to Kline (1962), mathematics proper, as we have often emphasized, deals with numbers, geometrical figures, and generalizations or extensions of ideas involving numbers and geometrical figure. It shows that the characteristic of mathematics is having an abstract object, thus a student is not easy to understand the mathematics material taught by the teacher. To anticipate such abstractions, mathematics needs to be visualized to be easily understood by students. In order to visualize the mathematics object, students must have a specific intelligence; the so-called spatial intelligence. Spatial intelligence is the ability to understand the visual material accurately, to transform and modify one's initial perception through visual observation and mental imagination and recreate aspects of the visual experience, even without the relevant physical stimuli (Gardner, 2011). Students with high spatial intelligence may have a better understanding in mathematics as in that the learning outcomes will be maximum.

Mathematics material should be hierarchically arranged and systematically from low school level to high school level, from low to high-grade classes. Therefore, the initial competence of students is one of the prerequisites to master the next learning in order to obtain better results. Initial competence of students is needed for teachers to determine the appropriate entry behavior line so that appropriate steps can be taken in the next lesson.

To date, the instructional model applied by a mathematics teacher in SHS 6 Kendari is a direct instructional model which only focuses on the teacher without trying other instructional models that can activate the students, consequently the increase of mathematics learning outcomes from year to year is not significant. Previous studies of McCormick, Clark, \& Raines (2015) and Killian \& Bastas (2015) show that learning process that involving students actively will increase: 1) motivation and interest in learning, 2) interaction between teachers and students, 3) critical thinking skills and solving problems, and 4) student performance. The results of those studies indicate that the instructional model which involves students actively will be able to grow the ability to think, to work, to be scholastic and to communicate as one of the important aspects in life skills. Thus, students can communicate the results of educational work systematically and can make the learning process become more qualified.

Mathematics is basically a subject where doing is more prominent than reading, and is one of the important subjects at the secondary school level (Adeniji at. Al; 2018). Several reasons have been linked to unsatisfactory student learning outcomes in mathematics including poor teacher learning models (Aminah at. al, 2018; Mulyono at. al, 2018; Retnawati et al., 2017; Turgut \& Turgut, 2018; Yerizon et al., 2018). Therefore, it is recommended for teachers to find effective learning models in order to gain an in-depth understanding of systematic knowledge structures and train students' thinking skills which in turn will lead to better learning outcomes.

Integrative instructional model is one model that can be applied to overcome the low quality of students. This model can help students to develop a deep and systematic 
knowledge framework and simultaneously train critical thinking skills (Niehaus et. al; 2017). In this instructional model, teachers provide a combination of facts and concepts within a matrix or other arrangement forms such as detailed maps or hierarchies. Under the guidance of teachers, students try to find patterns and causal relationships within the information. In its application, integrative instruction is not intended to enable students to remember specific facts or concepts, but to enable students to discover and understand the relationships among them, to formulate their explanations, and to consider additional possibilities (hypotheses). This model is different from the model of learning that is widely applied so far, i.e. direct instruction, in which learning in the classroom is dominated by structuralist/objectivist/behaviorist comprehension, which aims to keep students remembering information, then going on the memorial. The integrative model is based on the view that students build their own understanding of the topics they are learning rather than recording lessons in a systematically arranged form.

Huber et. al (2007), as quoted by Railean (2015) suggests that integrative instruction is developing the ability to create, recognize, and evaluate relationships between concepts of different fields or contexts. This definition provides an idea that integrative instruction is an essential process in which students combine information with experience to create new learning and meaning. In the process, students create, recognize, and evaluate the relationships between concepts and produce simple connections between ideas and experiences they gain from inside and outside the classroom.

In order to know the phenomenon of both types of integrative model and direct instructional model on mathematics, as well as how it relates to spatial intelligence and initial competence of student to improve mathematics learning outcomes, the influence of instructional models (i.e. integrative and direct) and spatial intelligence levels (i.e. high and low) towards learning outcomes by controlling for initial competence are essential to study. The integrative model is constructed on an inductive strategy which was first coined by Hilda Taba (1960) and popularized by Eggen and Kauchak (2012). This model is based on a controlled and structured discussion that allows teachers to focus on helping students obtain academic information while practicing complex reasoning skills. In integrative discussions, students have the opportunity to build organized personal understanding to gather knowledge and information that includes complex relationships between facts, concepts, and generalizations (Estes \& Mintz, 2014; Kilbane \& Milman, 2014).

The learning theory that underlies all integrative learning models is that of constructivism theory which confirms that learning is an active process in which learners use sensory input to build meaning from experience. The constructivist important principles as developed by John Dewey (1916), Resnick (1987), and Vygotsky (1962) are reflected in the integrative model, including (1) learners need to "do" something or involved in so-called "active learning" (2) people learn to learn because they are learning, (3) important action of building meaning is mental, (4) learning involves language, and (5) learning is social. The integrative model has steps or phases in learning that should be completed by teachers and students commonly referred to as 
Syntax. Eggen and Kauchak (2012) divide the four phases of the process of implementing integrative instructional models, including 1) explaining, comparing, and looking for patterns, 2) explaining similarities and differences, 3) formulating hypotheses, and 4) generalizing to form broad relationships (Kilbane \& Milman, 2014).

The direct instructional model was developed based on B. F. Skinner's (1953) view of the teaching-learning process, particularly the influence of operant conditioning theory, that all behaviors are generated from external stimuli. In the direct instructional model, a person's response or student behavior (learn) is directly related to the stimulus (learning) in the classroom. The direct instructional model has a positive effect on learning especially when it is used to teach content that can be broken down into discrete segments with observable and measurable results (Kilbane \& Milman, 2014). Flores \& Kaylor, (2007); Leno \& Dougherty (2007), that the direct instructional model is a learning model based on extensive and highly effective research results used to teach low motivated students and students with learning difficulties. This model involves teacher demonstrations and explanations coupled with student exercises and feedback to help them gain the real knowledge and skills required for further learning.

As described above, the role of the teacher is quite imperative to the direct instructional model. The arrangement and management of lessons learned by teachers will greatly determine the ability of students to master the knowledge, attitudes, and skills. Direct instruction is not only dominated by behavioristic principles. In its development, direct instruction also accommodates the principles of cognitive psychology, including the importance of attention processes and long-term memory storage in learning, the limited capacity of working memory, and the value of learning basic skills for autogenetic. In addition, the principles of learning in sociocultural theory may contribute to the direct instruction by emphasizing that teachers should provide sufficient scaffolding (especially in the early learning process) and involve students into small group activities in training sessions. The phase of the direct instructional model according to Eggen and Kauchak consists of four phases including (1) introduction, (2) presentation, (3) guided training, and (4) self-training (Eggen \& Kauchak, 2012).

Spatial intelligence is one of eight types of multiple intelligence developed by Howard Gardner. In short, spatial intelligence is defined as the ability to identify through visual observations and mental imagination (Williams \& Newton, 2007). More comprehensively, Taylor (2013) defines spatial intelligence as the ability to think in three dimensions in terms of spatial reasoning, mental imagery, image manipulation, graphics and artistic skills, and active imagination. Simply put, spatial intelligence is the ability to visualize concepts and relationships between concepts (Mckee, 2004). Spatial intelligence can also be stated as the ability to have the sensitivity to adapt to sharply visible visual forms, balance, color, lines, shapes, and space (Ross, 2005).

Students with spatial intelligence enjoy artistic activities, read maps, graphs, and diagrams, and think in pictures. They are able to visualize images clearly and can solve jigsaw puzzles easily. They often need to see images before they can understand the meaning of the words. Images can provide contextual hints for words and help students learn to read and spell and can recognize relationships between objects. In addition, 
students with spatial intelligence generally record the subject matter by drawing to retain the content. Students can learn to spell words by looking at pictures. The use of these images is very effective because every time students hear the word, they see a picture of the word and in the picture, there is the correct spelling. Remembering this picture allows them to translate the image into words to the written-page.

Sciltz et. al (2012) outlines a number of steps needed to understand the surrounding information related to spatial intelligence, as follows: (a) Spatial relationship: the ability to understand how objects are positioned in space, including left-right orientation and rotation, (b) Visual discrimination: the ability to recognize objects based on familiar characteristics and distinguish objects from one another, even if they are presented into different scenes, (c) Figure-ground discrimination: the ability to focus on visual details with background distractions, (d) Visual integration: the ability to integrate different parts object or event into a meaningful unity, (e) Visual closure: the ability to recognize familiar objects when they are not displayed in their entirety or completely visible, (f) Visual memory: the ability to accurately recall vital visual information, (g) Visual-motor integration: the ability to precisely remember and make a replica of a geometry, and (h) Visual perceptual ability: the ability to perceive and interpret information from surrounding environment.

The initial competence of student, also defined as "the sum of what an individual knows" (Murphy \& Alexander, 2005), is an important component that cannot be separated from the learning process itself. The importance of paying attention to the initial competence in learning is due to the fact that the initial knowledge is the raw material required for learning. This initial ability acts as a mental hook that will lead students to the new information. In addition, the initial competence is also the basic building of knowledge and skills material. According to Biemans and Simons (1996), as quoted by Campbell \& Campbell (2009), initial competence is all the knowledge that learners have when entering a potentially relevant learning environment to gain new knowledge.

The initial competence referred to this study is the initial knowledge in mathematics. Since mathematics is a well-organized structure, and its material arranged in a hierarchically interrelated manner between one material with others, the prerequisite knowledge or initial competence of students is an important thing that must be considered in the mathematics learning process. This shows that students' initial math skills have an influence on learning outcomes. Mathematics instructional model should be developed in order to give the opportunity to students in developing their knowledge gradually both horizontal and vertical. By paying attention to the students' initial competence, teachers are expected to develop a more appropriate instructional model that includes preparations of teaching materials, learning steps, and appropriate evaluation tools.

The previous study of Muthomi \& Mbugua (2014) suggests that there is a significant correlation between teacher instructional strategies and student learning outcomes. Pollack (2016) and Singer (2015) added that integrative instructional model can increase students' involvement actively in learning and improve students' understanding 
and independence in learning. Furthermore, the results of Andayani \& Gilang (2015) and Peet et al., (2011) concluded that in addition to improving students' understanding of acquiring knowledge, integrative instruction provides significant advantages to students related to the six dimensions of knowledge that are: 1) identifying, demonstrating and adapting to the knowledge gained in different contexts; 2) adapt to differences (people and situations) in order to create solutions; 3) understanding and directing self as a learner; 4) being a reflexive, accountable, and relational learner; 5) identifying and differentiating one's own and others' perspectives; and 6) developing a professional digital identity.

The investigation results of Turgut \& Yilmaz (2012) and Yarmohammadian (2014) emphasized the importance of spatial intelligence in mathematics learning and showed a significant correlation with student learning outcomes. In addition, geometry learning is closely related to students' spatial intelligence (Boaler, et. al; 2016); so that students with high spatial intelligence, with effective instructional models, will more easily build their mathematical knowledge than students with low spatial intelligence. In contrast, Jones \& Ramirez (2013) shows that indirect instruction, students have a great dependence on teachers in acquiring their knowledge, thus students with low spatial intelligence will feel more comfortable with structured and guided learning. This result is consistent with Zhang (2017) and Lamber \& Tan (2017) results, indicating that students with low spatial intelligence will be more effective if learned using teachercentered guided instructional models.

Based on the above description and supported by empirical research results, this study aims: (1) to distinguish the difference of mathematics learning outcomes of students who are taught by integrative instructional model and direct instructional model, after controlling students' initial competence, (2) to elaborate interaction between integrative and direct instructional models on the mathematics learning outcomes, associated with spatial intelligence of students, after controlling initial competence. The results of this study can be used to develop learning programs utilizing integrative learning models in schools, especially at the secondary school level, based on students' spatial intelligence and initial competency.

\section{METHOD}

The study was conducted at SHS 6 Kendari by quasi-experimental method measuring two main variables, i.e., dependent and independent variables. The dependent variable was the results of mathematics learning in 11th-grade students majoring in science. The independent variables consisted of two variables, including: (1) treatment variable, in this case, was the instructional model, consisted of integrative and direct learning model models, and (2) moderator variable, which was the students' spatial intelligence, consisted of high and low spatial intelligence. This study also took student's initial competence as covariate variable. It was an affixed variable that was not the focus of the research but might affect the results of research and could not be manipulated. The current study used quasi-experimental method designed by level $2 \times 2$ (Table 1 ). Sampling was carried out on 36 students of 11th grade majoring in science (1st class) as an experimental class and 36 students in 11 th grade majoring in science (2nd class) as a 
control class, with a simple random sampling technique. Both classes were then given a spatial intelligence test to get the research subjects by taking $27 \%$ of the upper group and $27 \%$ of the lower group, thus 10 people were obtained from each group (Osterlind, 2002).

The data on mathematics learning outcomes, spatial intelligence, and students' competence was obtained through tests of cone slice material that had been validated by experts and tested empirically in 12th-grade students of SHS 6 Kendari with the consideration that they had studied the material. The results of validity tests for mathematics learning outcomes instrument obtained 34 valid items out of 40 tested items with a reliability level of 0.89 , the spatial intelligence instruments yielded 48 valid items from 55 items (reliability level $=0.92$ ), and the initial ability instrument provided 25 valid items from 30 items (reliability level $=0.88$ ). Data analysis techniques include (1) descriptive analysis: used to find the average, median, standard of deviation, maximum and minimum values. (2) prerequisite analysis testing includes the normality test, homogeneity test, linearity test, and regression line alignment test, and (3) Inferential analysis: conducted through covariance analysis (ANCOVA). If there any interaction between treatment variables and attribute variables, then $\mathrm{t}$-test was further performed (Huitema, 2011).

Table 2

Quasi Experimental Design of level 2×2

\begin{tabular}{lll}
\hline Moderator variable & \multicolumn{2}{c}{ Treatment variable } \\
\cline { 2 - 3 } & $\begin{array}{l}\text { Integrative instructional model } \\
\left(\mathrm{A}_{1}\right)\end{array}$ & $\begin{array}{l}\text { Direct instructional model } \\
\left(\mathrm{A}_{2}\right)\end{array}$ \\
\hline High spatial & $\mathrm{A}_{1} \mathrm{~B}_{1}$ & $\mathrm{~A}_{2} \mathrm{~B}_{1}$ \\
intellegence $\left(\mathrm{B}_{1}\right)$ & {$[\mathrm{X}, \mathrm{Y}]_{11 \mathrm{k}}$} & {$[\mathrm{X}, \mathrm{Y}]_{21 \mathrm{k}}$} \\
& $\mathrm{k}=1,2, \ldots, \mathrm{n}_{11}$ & $\mathrm{k}=1,2, \ldots, \mathrm{n}_{21}$ \\
\hline Low spatial intellegence & $\mathrm{A}_{1} \mathrm{~B}_{2}$ & $\mathrm{~A}_{2} \mathrm{~B}_{2}$ \\
$\left(\mathrm{~B}_{2}\right)$ & {$[\mathrm{X}, \mathrm{Y}]_{12 \mathrm{k}}$} & {$[\mathrm{X}, \mathrm{Y}]_{22 \mathrm{k}}$} \\
& $\mathrm{k}=1,2, \ldots, \mathrm{n}_{12}$ & $\mathrm{k}=1,2, \ldots, \mathrm{n}_{22}$ \\
\hline
\end{tabular}

$\mathrm{A}_{1} \mathrm{~B}_{1}=$ students taught by integrative learning model which have high spatial intelligence, $A_{2} B_{1}=$ students taught by direct learning model which have high spatial intelligence, $A_{1} B_{2}=$ integrative learning model - low spatial intelligence, $A_{2} B_{2}=$ direct learning model - low spatial intelligence, $X=$ scores of students' initial competence in mathematics, $\mathrm{Y}=$ scores of mathematics learning outcome, $\mathrm{k}=$ group (sample of each cell).

\section{FINDINGS AND DISCUSSION}

Result of descriptive analysis is presented in table 3 . 
Table 3

Descriptive Analysis Result

\begin{tabular}{|c|c|c|c|c|c|}
\hline \multicolumn{2}{|c|}{ Statistical data } & \multicolumn{4}{|c|}{ Learning model (A) } \\
\hline & & \multicolumn{2}{|c|}{ Integrative instructional model $\left(\mathrm{A}_{1}\right)$} & \multicolumn{2}{|c|}{ Direct instructional model $\left(\mathrm{A}_{2}\right)$} \\
\hline \multicolumn{2}{|c|}{ Spatial intelligence (B) } & $\mathrm{X}$ & $\mathrm{Y}$ & $\mathrm{X}$ & $\mathrm{Y}$ \\
\hline \multirow[t]{6}{*}{$\mathrm{B}_{1}$} & $n$ & 10 & 10 & 10 & 10 \\
\hline & Average & 59.6 & 81.76 & 60 & 68.24 \\
\hline & Minimum & 48 & 73.53 & 48 & 55.88 \\
\hline & Maximum & 68 & 88.24 & 68 & 79.41 \\
\hline & Median & 60 & 82.35 & 60 & 67.65 \\
\hline & Standard of deviation & 5.48 & 4.56 & 6.53 & 8.18 \\
\hline \multirow[t]{12}{*}{$\mathrm{B}_{2}$} & $n$ & 10 & 10 & 10 & 10 \\
\hline & Average & 58.4 & 62.35 & 57.6 & 66.77 \\
\hline & Minimum & 52 & 52.94 & 48 & 52.94 \\
\hline & Maximum & 64 & 67.65 & 68 & 76.47 \\
\hline & Median & 58 & 63.24 & 58 & 69.12 \\
\hline & Standard of deviation & 4.7 & 5.15 & 6.85 & 7.73 \\
\hline & $n$ & 20 & 20 & 20 & 20 \\
\hline & Average & 59 & 72.06 & 58.8 & 67.5 \\
\hline & Minimum & 48 & 52.94 & 48 & 52.94 \\
\hline & Maximum & 68 & 88.24 & 68 & 79.41 \\
\hline & Median & 60 & 70.59 & 60 & 69.12 \\
\hline & Standard of deviation & 5 & 11.03 & 6.63 & 7.78 \\
\hline
\end{tabular}

Hypothesis I: Mathematics learning outcomes taught with integrative learning model are higher than direct learning model after controlling for initial competence

Results of descriptive analysis (Table 3) show that the average mathematics learning outcomes taught by integrative learning (A1) after controlling for initial competence (72.06) are higher than those of taught by direct learning model (A2) after controlling initial ability (67.5). The results are visually presented in Figure 1.

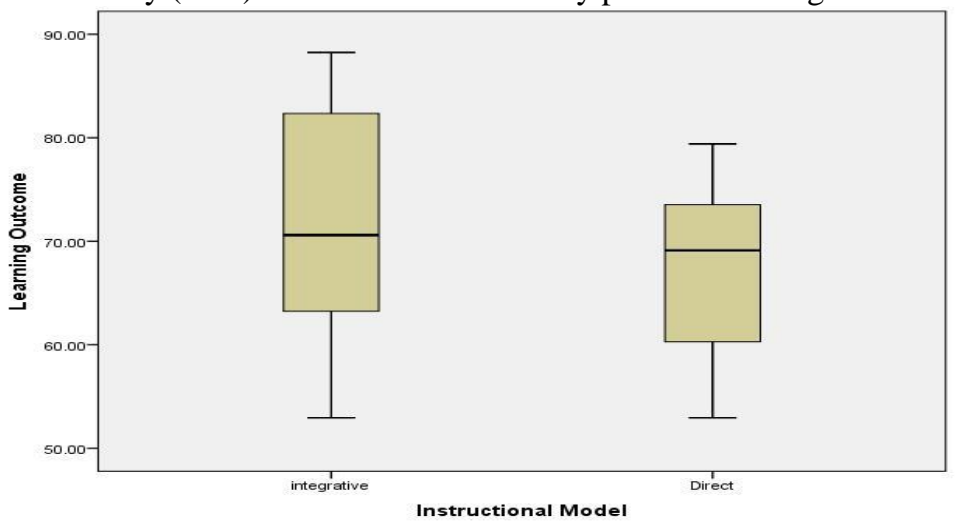

Figure 1

Boxplot Graph of Mathematics Learning Outcomes of Students Taught by Integrative and Direct Instructional Models

International Journal of Instruction, July $2019 \bullet$ Vol.12, No.3 
Table 4

Tests of Between-Subjects Effects (Dependent Variable: Y)

\begin{tabular}{llllll}
\hline Source & Type III Sum of Squares & Df & Mean Square & F & Sig. \\
\hline Corrected Model & $2646.518^{\mathrm{a}}$ & 4 & 661.630 & 22.678 & 0.000 \\
Intercept & 356.853 & 1 & 356.853 & 12.232 & 0.001 \\
X & 544.220 & 1 & 544.220 & 18.654 & 0.000 \\
A & 195.952 & 1 & 195.952 & 6.717 & 0.014 \\
B & 836.970 & 1 & 836.970 & 28.688 & 0.000 \\
A*B & 873.997 & 1 & 873.997 & 29.958 & 0.000 \\
Error & 1021.108 & 35 & 29.175 & & \\
Total & 198431.980 & 40 & & & \\
Corrected Total & 3667.626 & 39 & & & \\
\hline
\end{tabular}

${ }^{\mathrm{a}} \mathrm{R}$ Squared $=0.722$ (Adjusted R Squared $=0.690$ )

(Covariates appearing in the model are evaluated at the initial competence value $=$ 58.9000)

The result of two-way ANCOVA test (Table 3) shows that the source of variance among A obtained $F_{\text {count }}=6.717$ with the sig. $=0.014$ is smaller than $\alpha=0.05$. This means that there is a significant difference in mathematics learning outcomes between students taught by an integrative instructional model (A1) with those taught by direct instruction (A2) after controlling initial competence. The result of t-test (Table 5) obtained $t_{\text {count }}=$ $\mathrm{t}_{0(\mathrm{~A} 1 \times \mathrm{A} 2)}=2.592$ higher than $\mathrm{t}_{\text {table }}=\mathrm{t}_{(0.05 ; 37)}=1.684$; suggesting learning outcome by integrative instructional model is significantly higher than direct instruction after controlling students' initial competence. This result shows that the hypothesis I is accepted.

Table 5

Summary of Advanced Test Results after Controlling Initial Competence A1 vs A2

\begin{tabular}{llll}
\hline Compared Groups & Df & $\mathrm{t}_{\text {count }}$ & $\mathrm{t}_{\text {table }(\alpha=0.05)}$ \\
\hline A1 with A2 & 37 & 2.592 & 1.687 \\
\hline
\end{tabular}

This finding is in agreement with the results of previous studies (Estes \& Mintz, nd; Kilbane, R .; Milman, 2014; Paul D. Eggen, 2012) that integrative learning encourages students to actively develop their mathematical knowledge by connecting various facts, rules and concept which they have had with the new information they obtain and then proceed with building hypotheses and making conclusions through scientific procedures, while students who are taught with direct learning model will tend to be passive and not facilitate themselves to find experience based on their own knowledge. Becker \& Park (2011), Desjardins \& Slocum (1993), and Niehaus et al. (2017) further emphasizes that the integrative learning model is more effective than the direct learning model.

Hypothesis II: There is an influence of the interaction between learning models and spatial intelligence on students' mathematics learning outcomes after controlling for initial competence 
The result of descriptive analysis specifies that the mathematics learning outcome of students who have high spatial intelligence after controlling their initial competence that taught by the integrative instructional model has an average of 81.76 , while those taught by direct instruction has an average of 68.24. On the other hand, the learning outcome of students with low spatial intelligence after controlling initial competence has an average of 63.35 for an integrative instructional model, yet 66.7 for direct instruction. This indicates descriptively that there is an interaction effect between integrative and direct instructional models on the mathematics learning outcomes after controlling for initial competence of students. This, moreover, implies that mathematics learning outcomes for students with high spatial intelligence learned by integrative learning model are higher than those taught by direct learning model after controlling for initial competence, while learning outcomes for students with low spatial intelligence and taught by integrative learning model are lower than those by direct learning model after controlling for initial competence (Figure 2).

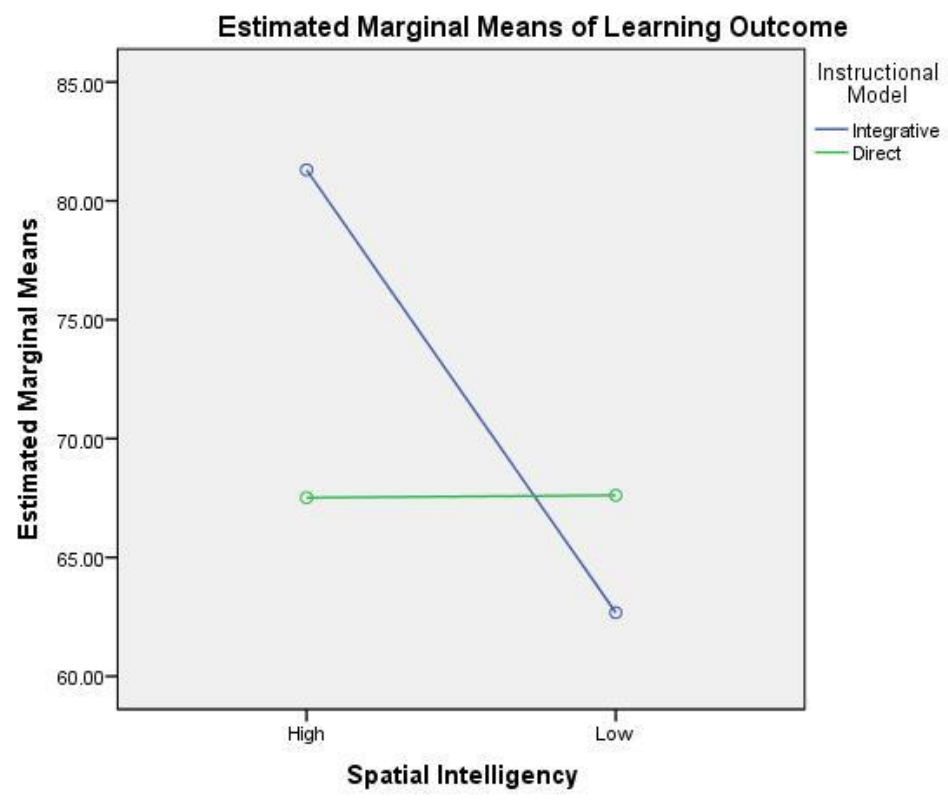

Figure 2

Graph of The Interaction Between Instructional Models and Spatial Intelligence on Mathematics Learning Outcomes After Controlling Students Initial Competence

The result of the ANCOVA test (Table 3), in line $\mathrm{A} \times \mathrm{B}$ interaction, obtained $\mathrm{F}_{\text {count }}=$ $\mathrm{F}_{0(\mathrm{~A} \times \mathrm{B})}=29.958$ with a value of sig. $=0.00$ less than $\alpha=0.05$; implying that there is a significant interaction effect between instructional models and spatial intelligence on students learning outcome after controlling their initial competence. This result shows that hypothesis II is accepted. 
This finding is in line with the result of the study conducted by Andayani \& Gilang (2015) that there is a significant positive interaction between integrative learning model and student learning interest in Indonesian Language learning outcomes for foreign students in Surakarta. Fazriyah (2017) emphasizes that there is an influence of interaction between the learning models and critical thinking on learning outcomes. Mulyono, Asmawi, \& Nuriah (2018) further explained that there is an influence of interaction between learning model and learning independence on mathematics learning outcomes by controlling initial competence.

Hypothesis III: Mathematics learning outcomes of students with high spatial intelligence who are taught by integrative learning model are higher than those taught by direct learning model after controlling for initial competence

The results of the descriptive analysis in table 2 show that the average mathematics learning outcomes for students with high spatial intelligence are taught by the integrative learning model (A1B1) after controlling for initial competencies (81.76) and those taught by the direct learning model (A2B1) after controlling initial competence (68.24). Visually these results are illustrated in Figure 3.

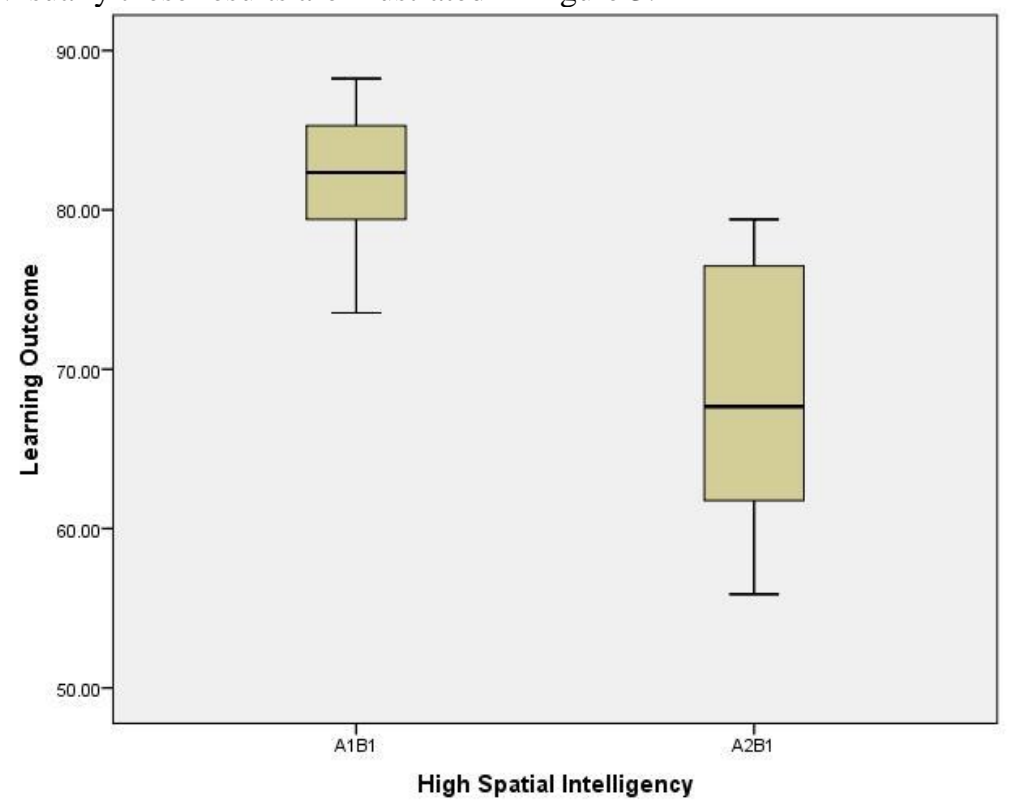

Figure 3

Mathematics Learning Outcomes of Students Who Have High Spatial Intelligence Taught by Integrative and Direct Instructional Models After Controlling for Initial Competence

Hypothesis III is tested using the t-test. The deduction is supported by further test result by using t-test in Table 6. 
Table 6

Summary of Advanced Test Results after Controlling Initial Competence

\begin{tabular}{lllll}
\hline No & Compared Groups & Df & $\mathrm{t}_{\text {count }}$ & $\mathrm{t}_{\text {table }}(\alpha=0.05)$ \\
\hline 1 & A1B1 with A2B1 & 17 & 5.708 & 1.74 \\
2 & A1B2 with A2B2 & 17 & -2.041 & 1.74 \\
\hline
\end{tabular}

The results of the analysis in Table 6 show that the value of $t_{\text {count }}=t_{0(\mathrm{~A} 1 \mathrm{~B} 1 \times \mathrm{A} 2 \mathrm{~B} 1)}=5.708$ is greater than the $t_{\text {table }}=1.74$ which means that the mathematics learning outcomes of students with high spatial intelligence that taught by integrative learning model are higher than those taught by direct learning model after controlling for initial competency. This indicates that hypothesis III is accepted.

This finding is in agreement with the study result of Zhao (2017) that integrative learning model will provide internal stimuli to students with high spatial intelligence to be able to process the learning given to build their knowledge for increasing the understanding of subject matter. On the other hand, students who have high spatial intelligence who tend to be active and like creative and explorative activities will easily become bored, lazy and lack of motivation in learning when taught by a direct learning model. This is because the direct learning is a teacher-centered learning model which is efficient and effective in teaching for targeted knowledge but inhibits the curiosity and creativity of students.

Hypothesis IV: Mathematics learning outcomes for students with low spatial intelligence taught by integrative learning model are lower than those taught by direct learning model after controlling for initial competence

The results of the descriptive analysis in Table 2 show that the average mathematics learning outcomes for students with low spatial intelligence taught by the integrative learning model (A1B2) after controlling for initial competence (62.35) is lower than the average learning outcomes of those taught by direct learning model (A2B2) after controlling for initial competence (66.77). Visually these results are explained in Figure 4. 


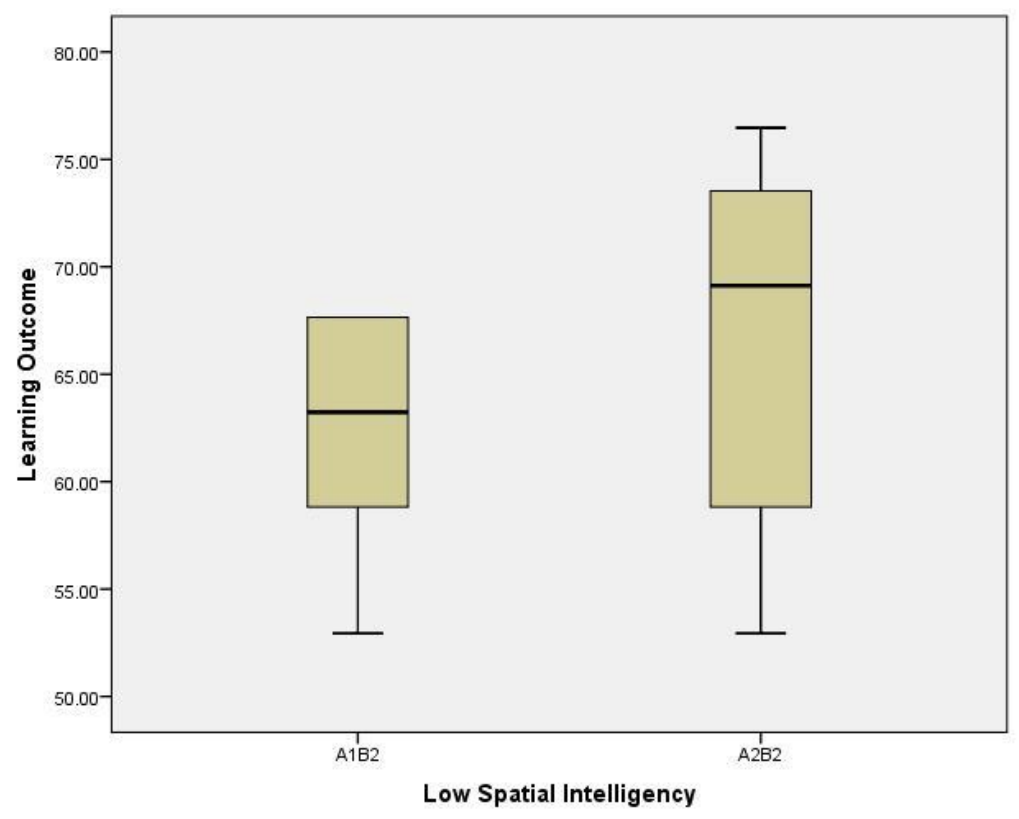

Figure 4

Mathematics Learning Outcomes of Students Who Have Low Spatial Intelligence Taught by Integrative and Direct Instructional Models After Controlling for Initial Competence

Further results by using $t$-test at table 5 obtained $t_{\text {count }}=t_{0(\mathrm{~A} 1 \mathrm{~B} 2 \times \mathrm{A} 2 \mathrm{~B} 2)}=-2.041$ is lower than $-t_{\text {table }}=-1.74$; suggesting that mathematics learning outcomes of students having low spatial intelligence taught by integrative instructional model were significantly lower than those of taught by direct instruction, after controlling for initial competence, therefore hypotheses IV is accepted.

This finding agrees with a previous study of Gersten et al. (2009) in Zhang (2017) which emphasized that direct learning model is more effective given to students who have learning disabilities. Students who have low spatial intelligence will be more effective when taught using a teacher-centered guided learning model (Lambert \& Tan, 2017). Students who have low spatial intelligence taught by an integrative learning model that requires students to be active will make students do not like activities that are creative and explorative, lazy and demotivated in learning. Geometry learning is very closely related to students' spatial intelligence; students who have high spatial intelligence, with effective learning models will be easier to build mathematical knowledge than students who have low spatial intelligence (Boaler, et. al, 2016).

\section{CONCLUSION}

This study summaries: Of the two instructional models being studied (i.e., integrative and direct instructions), the mathematics learning outcome of students who were taught 
by integrative instructional model was higher than direct instruction, after controlling students' initial competence; There is an interaction effect between instructional model and spatial intelligence on mathematics learning outcome after controlling for initial competence; Mathematics learning outcome with integrative instructional model of students having high spatial intelligence is higher than direct instruction, after controlling for initial competence; Mathematics learning outcome with integrative instructional model of students having low spatial intelligence is lower in comparison to direct instruction, after controlling for initial competency.

\section{RECOMMENDATIONS}

The following recommendations were produced based on the results of this study as follows: (1) In order to improve students' mathematics learning outcomes, integrative learning model is more suitable to be used, (2) In choosing a mathematical learning model, the teacher should pay attention to the individual characteristics of students, such as spatial intelligence and initial competence related to material being studied (3) Especially for students who have low spatial intelligence, the direct learning model is more appropriately applied in order to optimize students' learning outcomes, and (4) Further research is needed to apply integrative learning models to other materials in the field of mathematics at all levels of education, as well as further studying of the variables which may influence learning outcomes.

\section{REFERENCES}

Acharya, B. R. (2017). Factors affecting difficulties in learning mathematics by mathematics learners. International Journal of Elementary Education, 6(2), 8-15. doi: 10.11648/j.ijeedu.20170602.11.

Adeniji, S. M., Ameen, S. K., Dambatta, B. U., \& Orilonise, R. (2018). Effect of mastery learning approach on senior school students' academic performance and retention in circle geometry. International Journal of Instruction, 11(4). 951-962. doi: 10.12973/iji.2018.11460a.

Aminah, M., Kusumah, Y. S., Suryadi, D., \& Sumarmo, U. (2018). The effect of metacognitive teaching and mathematical prior knowledge on mathematical logical thinking ability and self-regulated learning. International Journal of Instruction, 11(3), 45-62. doi: 10.12973/iji.2018.1134a.

Andayani, \& Gilang, L. (2015). The effectiveness of integrative learning-based textbook toward the local culture comprehension and Indonesian language skill of foreign students. International Journal of Humanities and Social Science, 5(10-1), 197-207.

Becker, K., \& Park, K. (2011). Effects of integrative approaches among science, technology, engineering, and mathematics ( STEM ) subjects on students ' learning: A preliminary meta-analysis. Journal of STEM Education, 12(5), 23-38. doi: $10.1037 / \mathrm{a} 0019454$. 
Boaler, J., Chen, L., Williams, C., \& Cordero, M. (2016). Seeing as understanding: the importance of visual mathematics for our brain and learning. Journal of Applied \& Computational Mathematics, 5(5), 1-6.

Campbell, L., \& Campbell, B. (2009). Mindful learning: 101 proven strategies for student and teacher success. California: Corwin Press.

Cooper, J. D., Robinson, M. D., Slansky, J. A., \& Kiger, N. D. (2018). Literacy helping students construct meaning $10^{\text {th }}$. Boston: Cengage Learning.

Desjardins, E. A., \& Slocum, T. A. (1993). Integrating precision teaching and direct instruction. Journal of Precision Teaching 2(2), 20-24.

Eggen, P. D., \& Kauchak, D. P. (2012). Strategies and models for teachers: Teaching content and thinking skills. 6th ed. Boston: Pearson.

Estes, T. H., \& Mintz, S. L. (2016). Instruction: A models approach. New Jersey: Pearson.

Fazriyah, Supriyati, \& Rahayu. (2017). The effect of integrated learning model and critical thinking skill of science learning outcomes. Journal of Physics: Conference Series, 812(1), 1-6.

Flores, M. M., \& Kaylor, M. (2007). The effects of a direct instruction program on the fraction performance of middle school students at-risk for failure in mathematics. Journal of Instructional Psychology, 34, 84-94.

Gardner, H. (2011). Frames of mind: The theory of multiple intelligences. New York: Basic Book.

Huitema, B. E. (2011). The analysis of covariance and alternatives statistical methods for experiments, quasi-experiments, and single-case studies. New Jersey: John Wiley \& Sons.

Ishak, N., \& Awang, M. M. (2017). The relationship of student learning styles and achievement in history subject. The International Journal of Social Sciences and Humanities Invention, 4(3), 3372-3377.

Jones, D., \& Ramirez, H. (2013). Effects of direct instruction and corrective feedback on second language acquisition. National Forum of Educational Administration and Supervision Journal, 30(1), 64-87.

Kilbane, C. R., \& Milwan, N. B. (2014). Teaching models: Designing instruction for 21st-century learners. New Jersey: Pearson.

Killian, M., \& Bastas, H. (2015). The effects of an active learning strategy on students' attitudes and students' performances in introductory sociology classes. Journal of the Scholarship of Teaching and Learning, 15(3), 53-67.

Kline, M. (1962). Mathematics: A cultural approach. New York: Addison-Wesley. 
Lambert, R., \& Tan, P. (2017). Conceptualizations of students with and without disabilities as mathematical problem solvers in educational research: A critical review. Educational Sciences, 7(2), 1-18.

Leno, L. C., \& Dougherty, L. A. (2007). Using direct instruction to teach content vocabulary. Science Scope, 31, 63-66.

McCormick, N. J.; Clark, L. M., \& Raines, J. M. (2015). Engaging students in critical thinking and problem solving: A brief review of the literature. Journal of Studies in Education, 5(4), 100-113.

Mckee, L. (2004). The accelerated trainer using accelerated learning techniques to revolutionize your training. Burlington: Gower Publishing.

Mulyono, D., Asmawi, M., \& Nuriah, T. (2018). The effect of reciprocal teaching, student facilitator and explaining and learning independence on mathematical learning results by controlling the initial ability of students. International Electronic Journal of Mathematics Education, 13(3), 199-205. doi: 10.12973/iejme/3838.

Murphy, P. K., \& Alexander, P. A. (2005). Understanding how students learn: A guide for instructional leaders. California: Corwin Press.

Muthomi, M. W., \& Mbugua, Z. K. (2014). Effectiveness of differentiated instruction on secondary school students achievement in mathematics. International Journal of Applied Science and Technology, 4(1), 116-122

Niehaus, E., Holder, C., Rivera, M., Garcia, C. E., Woodman, T. C., \& Dierberger, J. (2017). Exploring integrative learning in service-based alternative breaks. The Journal of Higher Education, 88(6), 922-946. doi: 10.1080/00221546.2017.1313086.

Osterlind, S. J. (2002), Constructing test items: Multiple-choice, constructed-response, performance, and other formats. New York: Kluwer Academic Publishers.

Peet, M., Lonn, S., Gurin, P., Boyer, K. P., Matney, M., Marra, T., Taylor, S. H., \& Daley, A. (2011). Fostering integrative knowledge through ePortfolios. International Journal of ePortfolio, 1(1), 11-31.

Pehlivan, A., \& Durgut, M. (2017). The effect of logical-mathematical intelligence on financial accounting achievement according to multiple intelligence theory. Journal of Education \& Social Policy, 4(3), 132-139.

Pollack, S. (2016). Building bridges: Experiential and integrative learning in a Canadian women's prison. Journal of Teaching in Social Work, 35(5), 503-518.

Railean, E. (2015). Handbook of research on applied learning theory and design in modern education. Hershey, PA: IGI Global.

Retnawati, H., Kartowagiran, B., Arlinwibowo, J., \& Sulistyaningsih, E. (2017). Why are the mathematics national examination items difficult and what is teacher's strategy to overcome it? International Journal of Instruction, 10(3), 257-276. 
doi: 10.12973/iji.2017.10317a.

Ross, B. H. (2005). The psychology of learning and motivation: Advances in research and theory. San Diego: Academic Press.

Sciltz, K. L., Schonfeld, A. M., \& Niendam, T. (2012). Beyond the label a guide to unlocking a child's educational potential. New York: Oxford University Press.

Singer, K. P. (2015). Investigating the extent that an integrative learning module broadens the perception of first-year students about the engineering profession, American Journal of Engineering Education, 6(2), 99-112.

Taylor, A. (2013) Card magic and my mathematical discoveries. St, Raleigh: Lulu Publishing.

Turgut, M., \& Yilmaz, S. (2012). Relationships among preservice primary mathematics teachers' gender, academic success and spatial ability. International Journal of Instruction, 5(2), 1-20. doi: 10.13140/RG.2.1.3777.7448.

Turgut, S., \& Turgut, I. G. (2018). The effects of cooperative learning on mathematics achievement in Turkey: A meta-analysis study. International Journal of Instruction, 11(3), 663-680. doi: 10.12973/iji.2018.11345a.

Wahid, S. N. S., \& Yusof, Y. (2013). Math anxiety among students in higher education level, Procedia - Social and Behavioural Sciences, 123, 232-237.

Williams, R., \& Newton, J. (2007). Visual communication: Integrating media, art, and science. New Jersey: Taylor and Francis.

Yarmohammadian, A. (2014). The relationship between spatial awareness and mathematics disorders in elementary school students with learning mathematic disorder. Psychology and Behavioral Sciences, 1(1), 33-40.

Yerizon, Y., Putra, A. A., \& Subhan, M. (2018). Student responses toward student worksheets based on discovery learning for students with intrapersonal and interpersonal intelligence. IOP Conference Series: Materials Science and Engineering, 335(1), 97101. https://doi.org/10.1088/1757-899X/335/1/012113

Zhao, Y. (2017) What works may hurt: Side effects in education. Journal of Educational Change, 18(1), 1-19. doi: 10.1007/s10833-016-9294-4, 1-21.

Zhang, D. (2017). Effects of visual working memory training and direct instruction on geometry problem solving in students with geometry difficulties. Learning Disabilities: A Contemporary Journal, 15(1), 117-138. 